\title{
Technological possibilities of high-precision plasma cutting in processing materials of different class
}

\author{
Andrey Rakhimyanov ${ }^{1, *}$, Alexander Loktionov ${ }^{1}$, and Nadezhda Gaar $^{1}$ \\ ${ }^{1}$ Novosibirsk State Technical University, Faculty of Mechanical Engineering and Technologies, \\ 630073 Prospekt K. Marx 20, Novosibirsk, Russia
}

\begin{abstract}
Improving the technologies and equipment at a stage of the blank production in mechanical engineering greatly determines the reduction in the technological production costs. The use of modern technological complexes on cutting sheet materials provides a solution to tasks for increasing the accuracy of forming. Nowadays high-precision plasma cutting is developing. It can be considered as an alternative to the laser cutting in achieving high characteristics of the cut accuracy and quality. The paper under consideration presents the results of optimizing the processing speed for the existing schemes of high-precision plasma cutting in the range of the cut thickness from $1 \mathrm{~mm}$ to $30 \mathrm{~mm}$ for carbon steel, alloy steel and aluminum steel. The efficiency of using the technological scheme HiFocusplus for cutting such bimetallic compositions as "steel St3 + steel 12H18N10T", "steel St3 + aluminum A5M", "steel St3 + copper M1" is presented. It is determined that the best characteristics of the accuracy and quality of the cut are achieved in cutting the composition "steel ST3 + steel 12H18N10T" from the side of lowcarbon steel. Cutting from the side of aluminum and copper respectively is optimal for such compositions as "steel St3 + aluminum A5M" and "steel St3 + copper M1".
\end{abstract}

\section{Introduction}

The use of the processing methods that would allow reducing and excluding certain stages in the technological process is a perspective direction in decreasing the technological costs of detail manufacturing. Improving the equipment and technologies of the blank production greatly determines the costs at the stage of the mechanical processing. The implementation of new technologies based on using electro-physical processes allowed increasing the cut quality, excluding the necessity of creating the excessive oversize for the mechanical processing. Simultaneously, the use of new construction materials, such as amorphous and nanocrystalline alloys as well as layered compositions made of heterogeneous materials obtained by rolling or explosion welding requires the search for the effective methods of their processing, including the stage of the blank production.

\footnotetext{
*Corresponding author: centerfht@mail.ru
} 
At present, the high-precision plasma cutting of sheet metals is effectively applied in the blank production of the mechanical engineering both in the world and in Russia. The distinguishing feature of this technology is a combination of high process productivity inherent to the plasma-arc cutting and characteristics of the processing accuracy and quality typical of the laser cutting. It allows considering the high-precision plasma cutting as an alternative to the laser processing of the sheet metals with a thickness of up to $10 \mathrm{~m}$ [1]. The efficiency of such a technology in providing high accuracy characteristics, the quality and productivity during the processing of a wide range of metals and alloys gives the possibility to consider the high-precision plasma cutting as an innovation technology in the blank production [2-5]. The high-precision plasma cutting is provided by the technological schemes - HiFocus, HiFocusplus, HiFocusF - intended to cut materials in a certain thickness range.

The paper under consideration is devoted to summing up the results of experimental investigations on assessing the optimal values of the processing speed for different classes of metals and their compositions in applying the technological schemes of the highprecision plasma cutting.

\section{Methods of experimental investigations}

Experimental research was made on the technological complex of the high-precision plasma cutting equipped with the current source HiFocus 130, the structure and technical characteristics of which are described in Paper [6] in detail. Low-carbon steel St3, stainless steel 12H18N10T, aluminum A5M and bimetallic compositions "steel St3 + steel 12H18N10T", "steel St3 + aluminum A5M", "steel St3 + copper M1" obtained by explosion welding were chosen as the materials for investigations.

\section{Results and discussion}

The choice of a certain set of plasmatron elements for each technological scheme is determined by the thickness of the cut and type of the processed material. According to a chosen set of plasmatron elements, the composition of cutting and swirling gases as well as their flow and pressure are specified. The optimization of the processing according to the criteria of the cut accuracy and quality is possible due to varying the cutting speed and current. The cut deviation from the right angle, the roughness of its surface and the presence of the burr at the lower cut edge are estimated as the criteria of the accuracy and quality according to the standard ISO 9013:2002. Figure 1 represents the photos of the cut surface of low-carbon steel St3 after the processing at different speeds according to the HiFocus technology.
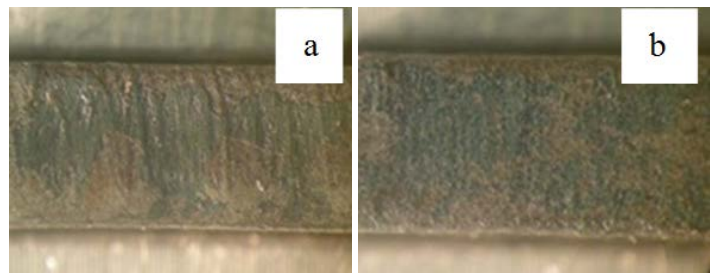

Fig. 1. Morphology of the cut surface of low-carbon steel St3 with a thickness of $3 \mathrm{~mm}$ during the processing at speeds according to the HiFocus technology: a) V=2.0 $\mathrm{m} / \mathrm{min} ; \mathrm{b}$ ) $\mathrm{V}=2.4 \mathrm{~m} / \mathrm{min}$

The processing speed $\mathrm{V}=2.2 \mathrm{~m} / \mathrm{min}$ is optimal for the cut thickness of $3 \mathrm{~mm}$ from the standpoint of accuracy and quality. The reduction in speed to $2.0 \mathrm{~m} / \mathrm{min}$ (Fig. 1a) leads to 
worsening the morphology of the cut surface. The increase in speed to $2.4 \mathrm{~m} / \mathrm{min}$ at a good quality of the cut (Fig. 1b) reduces the characteristics of the accuracy, increasing the cut deviation from the right angle to $5.8^{0}$ instead of $3.8^{0}$ at $\mathrm{V}=2.0 \mathrm{~m} / \mathrm{min}$.

The influence of the cutting current of stainless steel $12 \mathrm{H} 18 \mathrm{~N} 10 \mathrm{~T}$ on the surface morphology in using the HiFocus technology is shown in Figure 2.

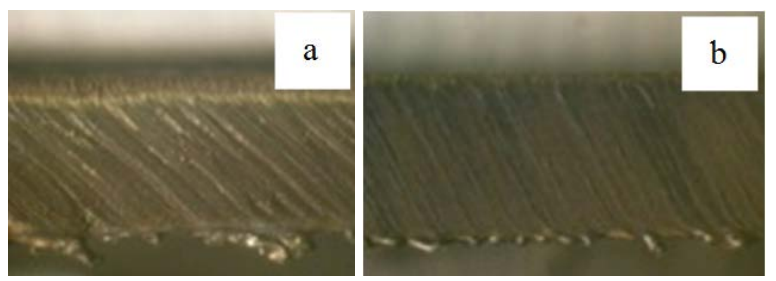

Fig. 2. Influence of the cutting current of stainless steel $12 \mathrm{H} 18 \mathrm{~N} 10 \mathrm{~T}$ with a thickness of $2 \mathrm{~mm}$ on the surface morphology in processing according to the HiFocus technology at a speed $\mathrm{V}=1.1 \mathrm{~m} / \mathrm{min}$ : a) $\mathrm{I}$ $=28 \mathrm{~A} ; \mathrm{b}) \mathrm{I}=30 \mathrm{~A}$

The increase in the cutting current from $\mathrm{I}=28 \mathrm{~A}$ to $\mathrm{I}=30 \mathrm{~A}$ results in reducing the surface roughness from $R_{a}=5.7 \mu \mathrm{m}$ to $R_{a}=2.6 \mu \mathrm{m}$ and decreasing the burr quantity at a lower cut edge.

The burr at a lower cut edge is practically absent in cutting low-carbon and stainless steels but its formation cannot be excluded in cutting aluminum at the investigated speed range of the processing (Figure 3). It is explained by a higher value of the kinematic viscosity of melted aluminum $\left(1.1 \cdot 10^{-6} \mathrm{~m}^{2} / \mathrm{sec}\right)$ in comparison with construction steels $\left(0.64 \cdot 10^{-6}-0.85 \cdot 10^{-6} \mathrm{~m}^{2} / \mathrm{sec}\right)$.
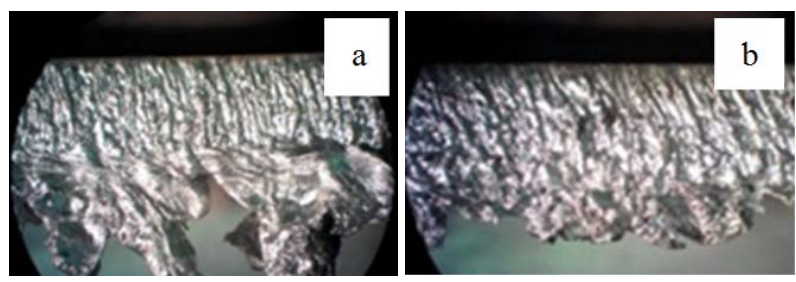

Fig. 3. Formation of the burr at the lower aluminum cut edge A5M with a thickness of $3 \mathrm{~mm}$ in processing according to the HiFocus technology: a) V=1.0 $\mathrm{m} / \mathrm{min}$; b) $\mathrm{V}=1.4 \mathrm{~m} / \mathrm{min}$

The increase in the processing speed leads to a certain reduction in the burr quantity (Figure $3 \mathrm{~b}$ ). It is explained by the fact that a narrowing of the cut channel and the decrease in the quantity of the liquid phase take place at higher speeds of processing, which provides a more effective removal of the melted metal in a narrow cut channel by the intensification of hydrodynamic flows.

The generalized results of investigations concerning the influence of the processing modes on the cut accuracy and quality as optimal speeds of cutting of the mentioned materials for the whole dimension range are shown in Figures $4-6$. The diagrams present possible combinations of the technological processing schemes at a cut thickness of $1-30$ $\mathrm{mm}$. So, the HiFocus technological scheme can be used in the processing of carbon steels only at a lower dimension range $(1-8 \mathrm{~mm})$. In this case, as the cut thickness increases, the reduction in the value of the optimal processing speed takes place. It is advisable to use the HiFocusplus technology at a cut thickness of $3-30 \mathrm{~mm}$, which provides the processing at higher speeds in comparison with the HiFocus technology. The HiFocusF technology provides the highest processing speed for the cut thickness of more than $8 \mathrm{~mm}$. It is implemented for the source used at the maximum current $\mathrm{I}=130 \mathrm{~A}$. However, the 
technology mentioned does not provide a high accuracy and quality of the cut, which assumes the further mechanical processing.

It should be noted that oxygen is used as the cutting gas and oxygen, nitrogen or oxygen-nitrogen mixture - as the swirl gas in processing carbon steels for all the technological schemes. The use of oxygen as a cutting gas allows implementing the elements of oxygen cutting in the plasma-arc cutting, which provides the higher speeds of the processing during carbon steel cutting (Figure 4).

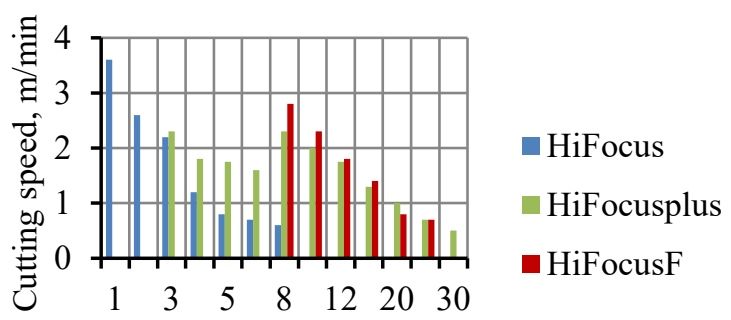

Dimensional range of thicknesses, $\mathrm{mm}$

Fig. 4. Speed parameters of carbon steel cutting in the dimensional range of thickness for different technological schemes of high-precision plasma cutting

The processing of alloy steels and aluminum supposes the change in cutting and swirl gases, which is accepted in using the HiFocus and HiFocusF technologies. Air is the cutting gas for the HiFocus technology, argon-hydrogen mixture (for alloy steels) and hydrogen (for aluminum alloys) - for the HiFocusF technology. Swirl gases for the HiFocus technology are presented by nitrogen-hydrogen mixture. Two swirl gases - nitrogen and nitrogen-hydrogen mixture - are simultaneously used for the HiFocusF technology.

The speed parameters of cutting for alloy steels and aluminum alloys are shown in Figures 5 and 6.

If there exist recommendations on choosing the technological schemes of high-precision plasma cutting in processing monomaterials, there is no such information on cutting bimetallic compositions. Papers [7 - 10] present the results of investigation on optimizing the operating parameters of the high-precision plasma cutting for bimetallic compositions "steel St3 + steel 12H18N10T", "steel St3 + aluminum A5M", "steel St3 + copper M1".

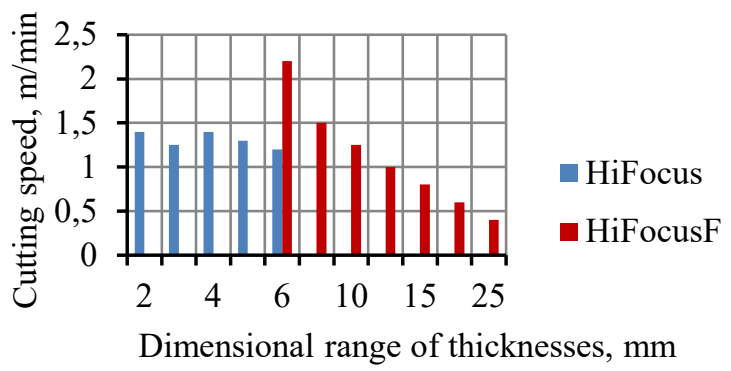

Fig. 5. Speed parameters of cutting alloy steels in the dimensional range of thicknesses for different technological schemes of high-precision plasma cutting

The optimization of the operating parameters was done according to the estimation of the cut accuracy and quality of the compositions in changing the front surface of the cutting 


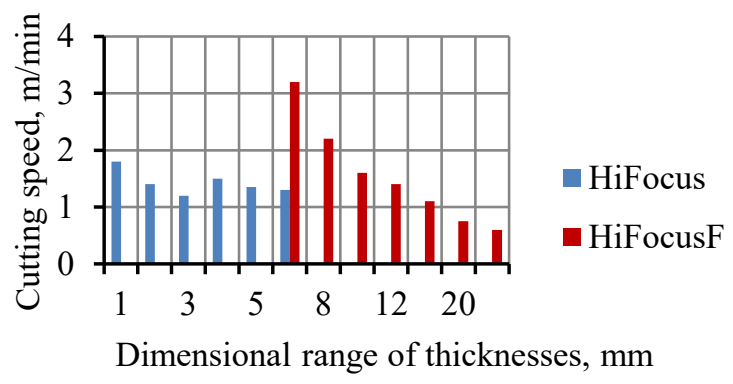

Fig. 6. Speed parameters of cutting aluminum alloys in the dimensional range of thicknesses for different technological schemes of high-precision plasma cutting

by using different technological schemes. As a result, it was established that the best results for the bimetallic materials mentioned were obtained in cutting by using the HiFocusplus technological scheme. It should be noted that low-carbon steel was the front surface of the cut for the composition "steel St3 + steel 12H18N10T" and aluminum and copper, respectively, - for the compositions "steel St3 + aluminum A5M" and "steel St3 + copper M1". The values of the optimal processing speed for the bimetallic compositions mentioned are presented in Figure 7.

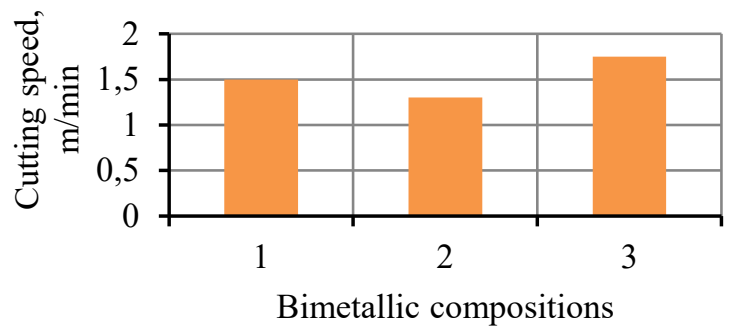

Fig. 7. Optimal cutting speed of bimetallic compositions according to the HiFocusplus technological scheme:

1 - "steel St3 + steel 12H18N10T" composition with a thickness of $5 \mathrm{~mm}$;

2 - "steel St3 + aluminum A5M" composition with a thickness of $6 \mathrm{~mm}$;

3 - "steel St3 + copper M1" composition with a thickness of $5 \mathrm{~mm}$

\section{Conclusions}

The generalized results of optimizing the processing speed of metals of different classes in the cut thickness range from $1 \mathrm{~mm}$ to $30 \mathrm{~mm}$ by the high-precision plasma cutting are presented. The optimization of the processing speed is done by taking into consideration the assessment of the cut accuracy and quality. The range of the cut thickness for implementing the technological schemes HiFocus, HiFocusplus and HiFocusF is determined. It is proved experimentally that the technological scheme HiFocusplus is considered to be the most effective for cutting bimetallic compositions such as "steel St3 + steel 12H18N10T", "steel St3 + aluminum A5M" and "steel St3 + copper M1". The best results in the cut accuracy and quality for the bimetallic composition "steel St3 + steel 12H18N10T" are achieved in cutting from the side of low-carbon steel and for the compositions "steel St3 + aluminum A5M" and "steel St3 + copper M1" - from the side of aluminum and copper, respectively. 


\section{References}

1. I. Kirkpatrick, High definition plasma-an alternative to laser technology, Aircraft Engineering and Aerospace Technology, v. 70, iss. 3, pp. 215-217 (1998)

2. Kh.M. Rakhimyanov, A.I. Zhuravlev, A.A. Loktionov, A.Kh. Rakhimyanov, Modelirovanie processov tonkostrujnoj plazmennoj rezki dlya obespecheniya tochnosti formirovaniya krivolinejnyh konturov [Modeling of processes of high-precision plasma cutting for ensuring accuracy of formation of curvilinear contours], Nauchnyj vestnik Novosibirskogo gosudarstvennogo tekhnicheskogo universiteta - Science bulletin of NSTU, no. 4 (37), pp. 123 - 134 (2009), (in Russian)

3. Kh.M. Rakhimyanov, A.A. Loktionov, Analiz pogreshnostej formoobrazovaniya pri tonkostrujnoj plazmennoj rezke metallicheskih materialov [Analysis of errors in forming trickle plasma cutting metal materials], Sbornik trudov Vserossiiskoi nauchno-prakticheskoi konferentsii "Sovremennye problem v tekhnologii mashinostroeniia", posvyashchennoi 100-letiiu so dnia rozhdeniia professora Mukhanova I.I. - Proceedings of the International Scientific and Practical Conference "Modern Problems in Mechanical Engineering Technology", dedicated to the 100th anniversary of the birth of professor Mukhanov I.I., Novosibirsk, pp. 151-153 (2009), (in Russian)

4. Kh.M. Rakhimyanov, A.A. Loktionov, Tochnost' formoobrazovaniya pri tonkostrujnoj plazmennoj rezke metallicheskih materialov i puti ee povysheniya [Shaping accuracy at high-precision plasma cutting of metal materials and the way of her increase], Obrabotka metallov (tekhnologiya, oborudovanie, instrumenty) - Metal Working and Material Science, no. 4 (45), pp. 31-32 (2009), (in Russian)

5. Kh.M. Rakhimyanov, N.P. Gaar, A.Kh. Rakhimyanov, A.A. Loktionov, Estimation of accuracy in forming construction steels by the hifocus technology of high-precision plasma cutting, 11 International forum on strategic technology (IFOST 2016): proc., Novosibirsk, 1-3 June 2016. - Novosibirsk: NSTU, Pt. 1, pp. 66-68 (2016)

6. A.Kh. Rakhimyanov, Vybor tekhnologicheskikh skhem $i$ optimizatsiya rezhimov tonkostruinoi plazmennoi rezki konstruktsionnykh stalei [Selection of technological schemes and high-precision plasma cutting mode optimization for structural steels], Obrabotka metallov (tekhnologiya, oborudovanie, instrumenty) - Metal Working and Material Science, no. 2 (63), pp. 46-55 (2014), (in Russian)

7. A.Kh. Rakhimyanov, Kh.M. Rakhimyanov, B.A. Krasil'nicov, Tekhnologicheskie osobennosti raskroya bimetallicheskogo soedineniya "stal' St3 + stal' 12X18H10T" pri tonkostruinoi plazmennoi rezke [Technological features cutting bimetallic connections «steel St3 + steel 12H18N10T» by high-precision plasma cutting], Obrabotka metallov (tekhnologiya, oborudovanie, instrumenty) - Metal Working and Material Science, no. 3 (64), pp. 51-67 (2014), (in Russian)

8. Kh. Rakhmyanov, A. Rakhmyanov, M. Heifetz, High-precision plasma cutting of the steel-aluminum bimetallic composition, Applied Mechanics and Materials, v. 788, pp. $41-45(2015)$

9. Kh. Rakhmyanov, A. Rakhmyanov, A. Zhuravlev, Advantages of high-precision plasma cutting for processing bimetallic compositions, Applied Mechanics and Materials, v. 698, pp. 294-298 (2015)

10. Kh.M. Rakhimyanov, A.Kh. Rakhimyanov, A.N. Smirnov, Osobennosti formirovaniya kanala reza pri tonkostrujnoj plazmennoj rezke bimetallicheskih kompozicij, vypolnennyh iz raznorodnyh materialov [Features of channel cut formation during high-precision plasma cutting of bimetallic compositions made from promiscuous materials], Obrabotka metallov (tekhnologiya, oborudovanie, instrumenty) - Metal Working and Material Science, no. 1 (70), pp. 22-30 (2016), (in Russian) 